\title{
Regional GIS-based evaluation of the potential and supply costs of forest biomass in Sweden
}

\author{
Dimitris ATHANASSIADIS (凶), Tomas NORDFJELL \\ Department of Forest Biomaterials and Technology, Swedish University of Agricultural Sciences, SE-90183 Umeå, Sweden
}

\begin{abstract}
The potential for harvestable forest fuel (logging residues and stumps from regeneration fellings and small diameter trees from early thinnings) in Sweden, divided in five regions, is provided. Marginal cost curves for logging residues and stumps are calculated through a GIS-based method based on forest inventory plots and locations of selected terminals, and heat and combined heat and power facilities. Four supply chains for logging residues and two for stumpwood were compared. Fixed and variable costs of harvesting equipment and transport vehicles were used for determining the costs of each of the supply systems under consideration. A list with the GPS coordinates of all facilities and terminals was made based on their geographical location. The distance from the center of each forest inventory plot to the nearest receiving point within the region, either facility or terminal, was estimated. There were large differences in the estimated potential of harvestable forest fuel between the regions. The overall annual potential for each of the five regions ranged from 0.97 to 2.73 million oven dry tonnes and the total potential amounted to $9.39 \mathrm{Mt}$ (oven dry). One of the northernmost regions (R1) had the steepest slope in its marginal cost curve. For the other regions, the slope of their cost curves was less dramatic. Information on the economic availability of logging residues and stumps in each region is important for forest fuel suppliers and receiving facilities.
\end{abstract}

Keywords GIS, logging residues, heat and-power facilities, stumpwood

\section{Introduction}

Public awareness of climate change, international obligations to decrease greenhouse gas emissions and the scarcity of fossil fuels have increased the interest in renewable

Received April 7, 2017; accepted October 24, 2017

Correspondence: Dimitris.Athanassiadis@slu.se energy sources. By 2020, the European Union aims to decrease the emissions of global warming gases by $20 \%$ (compared with the 1990 emission levels) while increasing the amount of energy coming from renewable resources to $20 \%$ of total energy production (2008: about $8.5 \%)^{[1]}$. As a consequence, the demand for wood as raw material for heat and power generation has increased considerably in Europe and globally. The Nordic countries have been active for more than 30 years and generally have well established renewable energy markets and supply chains for servicing these markets.

In Sweden, the use of bioenergy has increased by an average of $3.3 \mathrm{TWh} \cdot \mathrm{yr}^{-1}$ over the past 20 years. In 2013, it represented 35\% (130 TWh) of the total energy consumption $^{[2]}$. From 2003 to 2007, 44 new biofuel fired facilities were built in Sweden (mainly large scale combined heat and power facilities). This expansion has mainly been made possible through an increased use of forest industry by-products. Today and in the future, a further expansion requires an increased use of forest biomass ${ }^{[3]}$.

Potential forecasts and marginal cost curves for logging residues (branches and tops) and stumps from regeneration fellings for the period 2010-2019 for the whole of Sweden were reported by Athanassiadis et al. ${ }^{[4]}$. The forecasts were based on data from the Swedish National Inventory collected from 2002 to 2006 and specific assumptions on future forest management and regeneration fellings ${ }^{[5,6]}$. The forecasted annual potential assumes that Swedish silvicultural practices will not change and annual fellings will still be at a level that is regarded as sustainable, that environmental legislation will not change and that climate change will be light.

Three potential levels were estimated depending on a number of ecological and environmental, technical and economical restrictions. For Level 1 the only restriction was that areas of nature protection were excluded from the extraction of logging residues and stumps. For Level 2, and in addition to Level 1 restriction, a number of ecological restrictions were applied: wet areas, areas with peat soils with low bearing capacity, and areas located within $25 \mathrm{~m}$ of 
a lake, sea, waterline or any other ownership category other than forest were not considered for extraction of logging residues and stumps. For the rest of the areas the amount of extractable logging residues and stumps was reduced by $20 \%$ and no hardwood stumps were considered. For Level 3 a number of technical restrictions were taken into consideration, in addition to the ecological restrictions mentioned for Levels 1 and 2; a further 20\% (in total 40\%) of the logging residues and stumps were left on the ground in order to account for the current degree of logging residue recovery in the Nordic countries which is $60 \%{ }^{[7]}$. Areas that had an uneven ground structure and/or a slope of more than $19.6^{\circ}$ (degrees) according to the Swedish terrain classification scheme ${ }^{[8]}$ were not considered for extraction of logging residues and stumps and neither were regeneration felling areas of less than $1 \mathrm{hm}^{2}$.

The annual potential of harvestable logging residues and stumps, if no ecological and technical/economical restrictions were applied (Level 1), was estimated to be 7.4 and 11.7 million oven dry tons (ODT), respectively. If only ecological restrictions were applied (Level 2), the potential was estimated to be 5.1 and 6.9 million ODT, respectively and if both ecological and technical/economical restrictions were applied (Level 3) the potential was estimated to be 3.2 and 4.2 million ODT, respectively. It was found that logging residues can be harvested at a lower cost than stumps, which means that the marginal curve for logging residues starts at a lower level than the curve for stumps ${ }^{[4]}$. When the curves approached the harvestable potential they turned strongly upwards. It was argued that this was due to the fact that a part of the logging residue and stump potential is located in small production sites and/or far away from the industry, resulting in very high transport costs.

Harvest and transport costs of logging residues and stumps are site specific and differ due to site characteristics (i.e., size of operational units, tree size and species, varying terrain conditions, varying forwarding distances and harvest type), regional and local differences (i.e., operation overhead costs, logistics, acquisition of harvesting rights and customer demand) and harvesting system used (i.e., type of machinery, cost and productivity).

Heat and combined heat and power facilities (CHP) (hereafter referred to as facilities) are mainly located near bigger cities with an existing district heating distribution network and a high demand for heat. However, availability of potentially harvestable logging residues, stumps and small diameter trees varies regionally ${ }^{[9,10]}$ and is dispersed over large geographical areas. This makes the need for marginal cost curves that show the harvestable potential and the economic availability of logging residues, stumps and small diameter trees in different regions in Sweden imperative.

The aims of this paper were to (1) present regional harvestable potentials (restriction Level 3) of logging residues and stumps from regeneration fellings and small diameter trees from early thinnings and (2) to present regional marginal cost curves for logging residues and stumps for restriction Level 3

\section{Materials and methods}

Sweden was divided in five regions (R1-R5) (Fig. 1) which reflect the regional forest fuel market area for facilities. Forest inventory data from 2002 to 2006 were

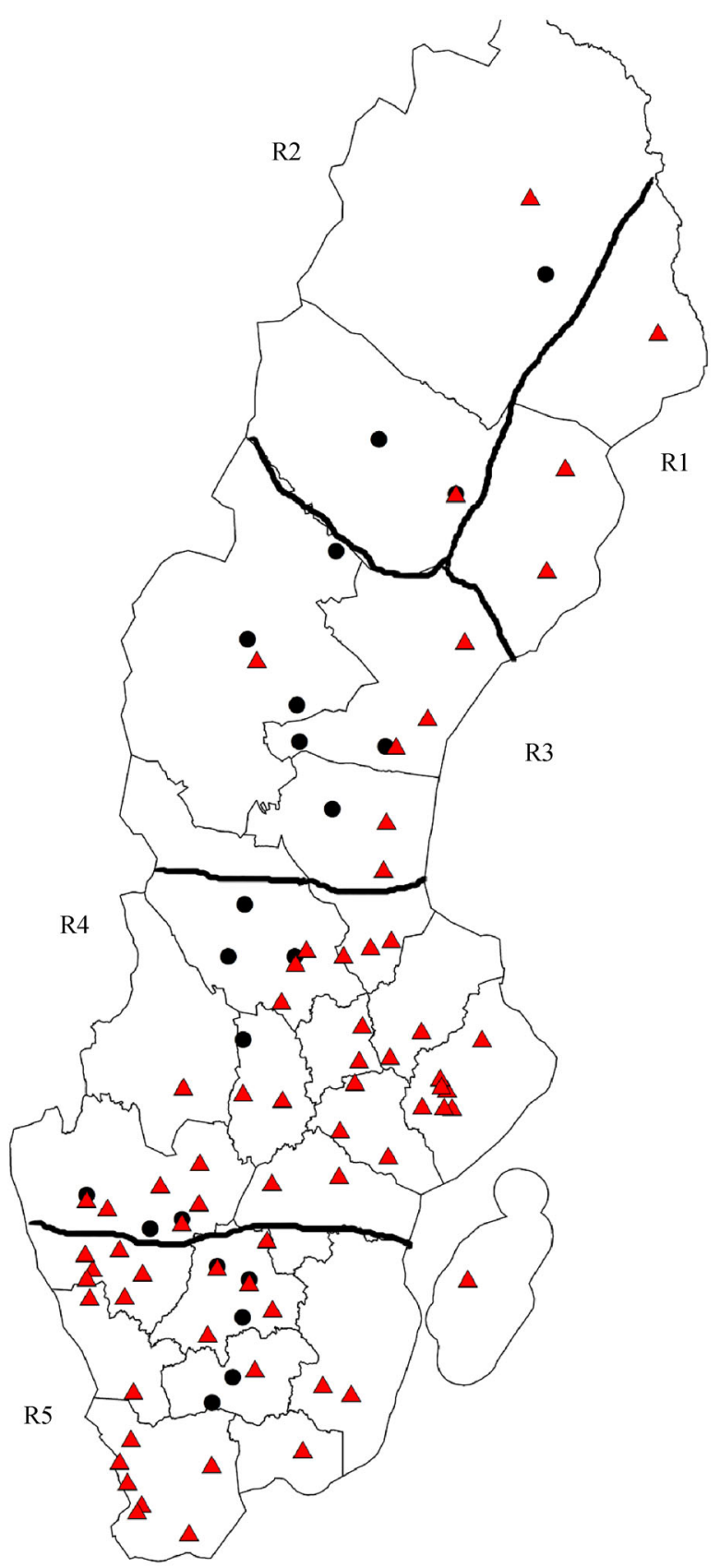

Fig. 1 Division of Sweden in regions (R1-R5). Triangles denote facilities that consumed $>100 \mathrm{GWh}$ of bioenergy in 2009 and dotes denote terminals. 
used to estimate the annual potential of harvestable logging residues and stumps from regeneration fellings and small diameter trees from early thinnings for the period 2010 2019. Each individual plot was used as the unit for decision for different future silvicultural and felling measures and a growth prognosis for the trees of each plot was produced. With respect to logging residues and stumps, each forest inventory plot represented an average of 14 regeneration felling sites of an average of $5.5 \mathrm{hm}^{2}$. A total of 30712 sites were included in the analysis.

The annual potential from the early thinning of areas with small diameter trees was calculated by estimating the amount of extracted biomass in stands in which the dominant tree species was $<14 \mathrm{~m}$ tall and where the removal quantity would be $>30 \mathrm{ODT} \cdot \mathrm{hm}^{-2}$.

Four supply chains for logging residues and two supply chains for stumpwood were defined (Table 1). Each supply chain and harvesting technology consisted of a number of work phases. Productivity and cost for each of these phases was estimated based on existing literature (summarized in Athanassiadis et al. ${ }^{[11]}$ ) and additional data from forest companies. Logging residues were forwarded to the roadside, chipped at roadside (Logging residues-Systems 1,3 and 4) and transported to the nearest facility or terminal. Alternatively, logging residues were transported uncomminuted to the nearest facility or terminal to be chipped (Logging residues-System 2). Stumps were lifted and forwarded to the roadside where they were crushed and transported to the nearest facility or terminal (StumpsSystem 1). Alternatively, the stumps were transported uncomminuted to the nearest facility or terminal and crushed there (Stumps-System 2) (Table 1).

Bioenergy consumption levels for each facility were supplied by the Swedish District Heating Association (SDHA) and Energy Market Inspectorate (EMI). Only facilities that had reported to have consumed more than $100 \mathrm{GWh}$ of bioenergy in 2009 according to EMI were considered. The EMI list was compared to the list provided by SDHA that included detailed consumption data from 2008. Finally, 67 facilities were selected for the analysis. In addition, 21 existing terminal sites were considered (Table 2).

Based on the geographic location of each facility and terminal a list with the GPS coordinates of all facilities and

Table 1 Structure of supply chains for logging residues and stumps from regeneration fellings

\begin{tabular}{|c|c|c|c|c|c|}
\hline Item & System & Harvesting site & Roadside & Road transport & Facility/Terminal \\
\hline \multirow[t]{4}{*}{$\begin{array}{l}\text { Logging } \\
\text { residue }\end{array}$} & System 1* & Forwarder & $\begin{array}{l}\text { Chipper mounted on } \\
\text { forwarder chassis }\end{array}$ & $\begin{array}{l}\text { Truck equipped with } \\
\text { bucket loader }\end{array}$ & - \\
\hline & System $2 * *$ & Forwarder & - & Logging residue truck & Crusher \\
\hline & System $3 * * *$ & Forwarder & Chipper mounted on truck & Chipper truck & - \\
\hline & System $4 * * * *$ & Forwarder & $\begin{array}{c}\text { Chipper mounted on forwarder } \\
\text { chassis }\end{array}$ & Bin truck & - \\
\hline \multirow[t]{2}{*}{ Stump } & System $1 *$ & $\begin{array}{l}\text { Stump harvester, } \\
\text { forwarder }\end{array}$ & crusher & $\begin{array}{l}\text { Truck equipped with } \\
\text { bucket loader }\end{array}$ & - \\
\hline & System $2 * *$ & $\begin{array}{l}\text { Stump harvester, } \\
\text { forwarder }\end{array}$ & - & Stump truck & Crusher \\
\hline
\end{tabular}

Note: *, Logging residues are comminuted directly on the ground and the chips are picked up by a truck equipped with a bucket loader; **, logging residues or stumps are transported loose by a loader equipped truck; $* * *$, comminution and road transportation of chips is made with a so-called integrated chipper-chip truck ${ }^{[6]}$; $* * * *$, logging residues or stumps are comminuted in containers which are then loaded on a bin truck.

Table 2 Number of inventory plots, facilities and terminals associated with each region (R1-R5, Fig. 1)

\begin{tabular}{lccc}
\hline Region & Inventory plot & Facilitiies & Terminal \\
\hline R1 & 243 & 4 & - \\
R2 & 304 & 2 & 4 \\
R3 & 385 & 5 & 6 \\
R4 & 631 & 26 & 3 \\
R5 & 640 & 30 & 8 \\
Total & 2203 & 67 & 21 \\
\hline
\end{tabular}


terminals was made. Information on the location of terminals was collected from forest companies throughout the country. All extraction distances (geodetic distances) were estimated by the forest inventory personnel. A winding coefficient of 1.2 on the extraction distance was applied independently of the region ${ }^{[11]}$. The distance from the center of the forest inventory plot to the nearest receiving point within the region, either facility or terminal, was estimated based on the Swedish road network by using the Network Analyst module in ArcGIS10.

Fixed and variable costs of harvesting equipment and transport vehicles included in v Hofsten et al. ${ }^{[12]}$ together with the additional data from the forest industry were used for appreciating the cost of each of the supply systems under consideration. In Table 3 machine productivity and costs for the machinery involved in stump and logging residues supply systems are presented.

Forwarder extraction costs $\left(\mathrm{F}_{\mathrm{c}}\right)\left(\mathrm{EUR} \cdot \mathrm{ODT}^{-1}\right)$ were a function of the extraction distance $\left(\mathrm{A}_{\mathrm{F}}\right)(\mathrm{m})$ to the nearest forest road (Table 4). Similarly, road transportation costs
(EUR $\left.\cdot \mathrm{ODT}^{-1}\right)$ for bucket trucks $\left(\mathrm{RC}_{\mathrm{B}}\right)$, logging residue trucks $\left(\mathrm{RC}_{\mathrm{LR}}\right)$, chipper trucks $\left(\mathrm{RC}_{\mathrm{CH}}\right)$ bin trucks $\left(\mathrm{RC}_{\mathrm{BT}}\right)$ and stump trucks $\left(\mathrm{RC}_{\mathrm{S}}\right)$ were a function of the distance $\left(\mathrm{A}_{\mathrm{D}}\right)(\mathrm{km})$ to the nearest terminal or facility (Table 4). The rest of the equipment was allocated a fixed cost per ODT of biomass.

\subsection{Assumptions and constraints}

(a) All costs for harvesting of logging residues and the cost of piling logging residues into heaps in conjunction with a regeneration felling operation are included in the roundwood harvesting costs.

(b) For all biomass (logging residues, stumps and small diameter trees) an effective heating value of $19.2 \mathrm{GJ} \cdot \mathrm{ODT}^{-1}$ at a natural ash content of $1 \%$ dry weight was assumed ${ }^{[13]}$. The moisture content was set to $50 \%$ of fresh weight for all biomasses. The net energy content was then calculated to $4.65 \mathrm{MWh} \cdot \mathrm{ODT}^{-1}$, according to Ring$\operatorname{man}^{[13]}$. The oven-dried mass density of the fresh comminuted biomasses was set to $0.17 \mathrm{ODT} \cdot \mathrm{m}^{-3}$ loose

Table 3 Machine productivity and cost estimates for the machinery involved in logging residues and stump supply systems

\begin{tabular}{|c|c|c|c|c|c|c|c|c|c|c|}
\hline Item & $\begin{array}{l}\text { Stump } \\
\text { lifting }\end{array}$ & $\begin{array}{l}\text { Forwarding } \\
\text { (logging } \\
\text { residues } \\
\text { and stumps) } \\
180 / 420 \mathrm{~m}^{*}\end{array}$ & $\begin{array}{l}\text { Chipping } \\
\text { at } \\
\text { roadside }\end{array}$ & $\begin{array}{l}\text { Crushing } \\
\text { at } \\
\text { roadside } \\
\text { or } \\
\text { terminal }\end{array}$ & $\begin{array}{l}\text { Crushing } \\
\text { at facility }\end{array}$ & $\begin{array}{c}\text { Bucket } \\
\text { truck } \\
50 / 100 \\
\mathrm{~km}^{* *}\end{array}$ & $\begin{array}{c}\text { Logging } \\
\text { residues } \\
\text { truck } \\
50 / 100 \\
\mathrm{~km}^{* *}\end{array}$ & $\begin{array}{c}\text { Stump truck } \\
50 / 100 \\
\mathrm{~km}^{* *}\end{array}$ & $\begin{array}{c}\text { Container } \\
\text { truck } \\
50 / 100 \\
\mathrm{~km}^{* *}\end{array}$ & $\begin{array}{c}\text { Chipper } \\
\text { truck } \\
50 / 100 \\
\mathrm{~km}^{* *}\end{array}$ \\
\hline Capital cost $/\left(\mathrm{kEUR} \cdot \mathrm{yr}^{-1}\right)$ & 43.78 & 44.44 & 74.47 & 108.57 & 99.22 & 76.67 & 61.93 & 61.93 & 47.41 & 119.13 \\
\hline Personal cost $/\left(\mathrm{kEUR} \cdot \mathrm{yr}^{-1}\right)$ & 122.32 & 122.32 & 111.76 & 111.76 & 81.51 & 100.76 & 100.76 & 100.76 & 100.76 & 100.76 \\
\hline Operating cost $\left(\mathrm{kEUR} \cdot \mathrm{yr}^{-1}\right)$ & 78.76 & 95.92 & 149.05 & 503.91 & 356.29 & 90.2 & 81.73 & 81.73 & 74.36 & 107.47 \\
\hline Total cost/(EUR $\left.\cdot \mathrm{h}^{-1 * * *}\right)$ & - & - & - & - & - & 87.78 & 80.85 & 80.85 & 74.25 & 110.44 \\
\hline Total cost $/\left(\mathrm{EUR} \cdot \mathrm{E}_{15} \mathrm{~h}^{-1 * * * *)}\right.$ & 95.81 & 97.24 & 165.44 & 284.02 & 187.11 & - & - & & - & - \\
\hline Loading/min & - & 24 & - & - & - & 30 & 50 & 50 & 45 & 90 \\
\hline Unloading/min & - & 9 & - & - & - & 15 & 40 & 40 & 25 & 25 \\
\hline $\begin{array}{l}\text { Load size (raw tonnes) }(50 \% \text { moisture } \\
\text { content) }\end{array}$ & - & 8,5 & - & - & - & 30 & 24 & 20 & 36 & 26 \\
\hline Productivity $/\left(\mathrm{ODT} \cdot \mathrm{h}^{-1}\right)$ & - & - & - & - & - & $5.5 / 3.2$ & $3.4 / 2.2$ & $2.9 / 1.8$ & $5.1 / 3.1$ & $3.3 / 2.2$ \\
\hline Productivity/(ODT $\left.\cdot \mathrm{E}_{15} \mathrm{~h}^{-1}\right)$ & 3.7 & $5.5 / 4.3$ & 11 & 17 & 20.5 & - & - & - & - & - \\
\hline $\operatorname{Cost} /\left(\mathrm{EUR} \cdot \mathrm{ODT}^{-1}\right)$ & 25.63 & $17.93 / 22.88$ & 14.96 & 16.61 & 9.19 & $16.17 / 27.7$ & $3.32 / 36.52$ & $228.27 / 44.44$ & $4.74 / 24.0$ & $33.33 / 50.38$ \\
\hline
\end{tabular}

Note: *, At forwarding distance of 180 or $420 \mathrm{~m} ; * *$, a hauling distance of 50 or $100 \mathrm{~km} ; * * *$, scheduled working hours; ****, working time including delay times shorter than $15 \mathrm{~min}$.

Table 4 Distance depended cost functions for forwarders and trucks. $A_{\mathrm{F}}(\mathrm{m}), A_{\mathrm{D}}(\mathrm{km})$ while $F_{\mathrm{C}}, \mathrm{RC}_{\mathrm{B}}, \mathrm{RC}_{\mathrm{LR}}, \mathrm{RC}_{\mathrm{C}}, \mathrm{RC}_{\mathrm{CH}}, \mathrm{RC}_{\mathrm{S}}$ are in $\mathrm{EUR} \cdot \mathrm{ODT}^{-1}$

\begin{tabular}{lcc}
\hline Type & \multicolumn{2}{c}{ Cost function } \\
\cline { 2 - 3 } & \multicolumn{1}{c}{ Logging residue } & $F_{\mathrm{C}}=14.2+\left(0.02 \times A_{\mathrm{F}}\right)$ \\
\hline Forwarder & $F_{\mathrm{C}}=14.2+\left(0.02 \times A_{\mathrm{F}}\right)$ & - \\
Bucket truck & $\mathrm{RC}_{\mathrm{B}}=4.60+\left(0.23 \times A_{\mathrm{D}}\right)$ & - \\
Logging residues truck & $\mathrm{RC}_{\mathrm{LR}}=10.11+\left(0.26 \times A_{\mathrm{D}}\right)$ & $\mathrm{RC}_{\mathrm{BT}}=5.40+\left(0.19 \times A_{\mathrm{D}}\right)$ \\
Bin truck & $\mathrm{RC}_{\mathrm{BT}}=5.40+\left(0.19 \times A_{\mathrm{D}}\right)$ & - \\
Chipper truck & $\mathrm{RC}_{\mathrm{CH}}=16.17+\left(0.34 \times A_{\mathrm{D}}\right)$ & $\mathrm{RC}_{\mathrm{S}}=12.45+\left(0.32 \times A_{\mathrm{D}}\right)$ \\
Stump truck & - & \\
\hline
\end{tabular}


raw comminuted material, which corresponds to an energy density of $0.82 \mathrm{MWh} \cdot \mathrm{m}^{-3}$ loose raw comminuted material. Payment to the forest owner was priced at 18.92 EUR $\cdot$ ODT $^{-1}$. Forest company administration costs were estimated to $8.14 \mathrm{EUR} \cdot \mathrm{ODT}^{-1}$. Shifting cost (moving to the harvesting site) for harvesters, forwarders, chippers and crushers were set to 275 EUR per machine.

(c) Each region was treated in isolation so transport of logging residues and stumps between regions was not considered.

(d) Bioenergy consumption by the facilities refers to consumption of logging residues, bark, sawmill byproducts, wood waste, pellets, briquettes and peat.

(e) Existing facility and terminal storage capacities were not considered.

\section{Results}

\subsection{Regional potentials}

There were large differences between regions and their estimated potential to supply logging residues and stumps from regeneration fellings and small trees from early thinnings (Table 5). The total potential for the five different regions ranged from about 0.97 to 2.73 million $\mathrm{ODT} \cdot \mathrm{yr}^{-1}$. R4 presented the highest potential (29\% of total potential) while R1 the lowest (10\% of total potential).

\subsection{Regional marginal cost curves for logging residues}

$\mathrm{R} 1$ had the steepest slope in its marginal cost curve rising up from 66 to $121 \mathrm{EUR} \cdot \mathrm{ODT}^{-1}$ in just 0.35 million ODT (the whole annual potential). This sharp rise indicates that the cost for achieving small increases in the extracted quantity is quite high (Fig. 2). This was the case for all the systems considered. For regions R2, R3, R4 and R5 the slopes were less dramatic. Logging residues economic availability was best for regions R4 and R5. For these regions, cost increase for extracting more logging residues was moderate (Fig. 2). In R1, R2 and R3, the system that was the cheapest was Logging residues-System 4, i.e., logging residues forwarded to the roadside, chipped at roadside by a mobile chipper based on a forwarder and transported to the nearest facility or terminal by means of a container truck. In R4 and R5, the cheapest one was Logging residues-System 3 where logging residues were forwarded to the roadside, chipped at roadside by a truck mounted chipper and transported to the nearest facility or terminal.

\subsection{Stump marginal cost curves}

R1 had the steepest slope in its stump marginal cost curve rising from 99 to $165 \mathrm{EUR} \cdot \mathrm{ODT}^{-1}$ in just 0.5 million ODT (the whole annual potential). As in the case of logging residues, this sharp rise indicates that the cost for achieving small increases of the extracted quantity of stumps is quite high. This was the case for both systems. For regions R2, R3, R4 and R5 the slopes were less dramatic. As with the logging residues, stump economic availability was best for regions R4 and R5. For these regions, the cost increase for extracting more stumps was moderate (Fig. 3). In all regions it seems to be more economical to crush the stumps at the roadside and transport the crushed material to the terminal/facility than transporting whole stumps to the terminal/facility.

\subsection{Balance of forest fuels}

The total amount of logging residues, stumps and small diameter trees that are potentially available at Level 3 have an inherent energy of 43.7 TWh. The bioenergy demand of the facilities that were included in this study (i.e., those with an annual bioenergy demand of more than $100 \mathrm{GWh}$ ) totaled about $28 \mathrm{TWh}$. In the presumptive case that all other existing facilities (Table 6) (i.e., those with an annual bioenergy demand of less than $100 \mathrm{GWh}$ ) were also included in this study, the total demand for bioenergy would have been $34.3 \mathrm{TWh}$, i.e., about $80 \%$ of existing potential of logging residues, stumps and small diameter trees together. The balance between potential and demand varies regionally (Table 6). Only R5 had some kind of equilibrium (surplus of about $1 \mathrm{TWh}$ ). The deficit is obvious in R4, where the greatest part of the Swedish population resides and where demand for heat is greatest. The less inhabited regions (R1, R2 and R3) show an annual surplus of $14.3 \mathrm{TWh}$ being able to consume only $26 \%$ of the potential (Table 6).

Table 5 Regional technical potential (Level 3) for supplying logging residues and stumps from regeneration fellings and small trees from early thinnings (million ODT)

\begin{tabular}{lcccc}
\hline Region & Logging residue & Stump & Small tree & Sum \\
\hline R1 & 0.36 & 0.51 & 0.10 & 0.97 \\
R2 & 0.46 & 0.63 & 0.17 & 1.26 \\
R3 & 0.61 & 0.87 & 0.44 & 1.92 \\
R4 & 0.87 & 1.17 & 0.69 & 2.73 \\
R5 & 0.87 & 1.06 & 0.58 & 2.51 \\
Whole Sweden & 3.17 & 4.24 & 1.98 & 9.39 \\
\hline
\end{tabular}



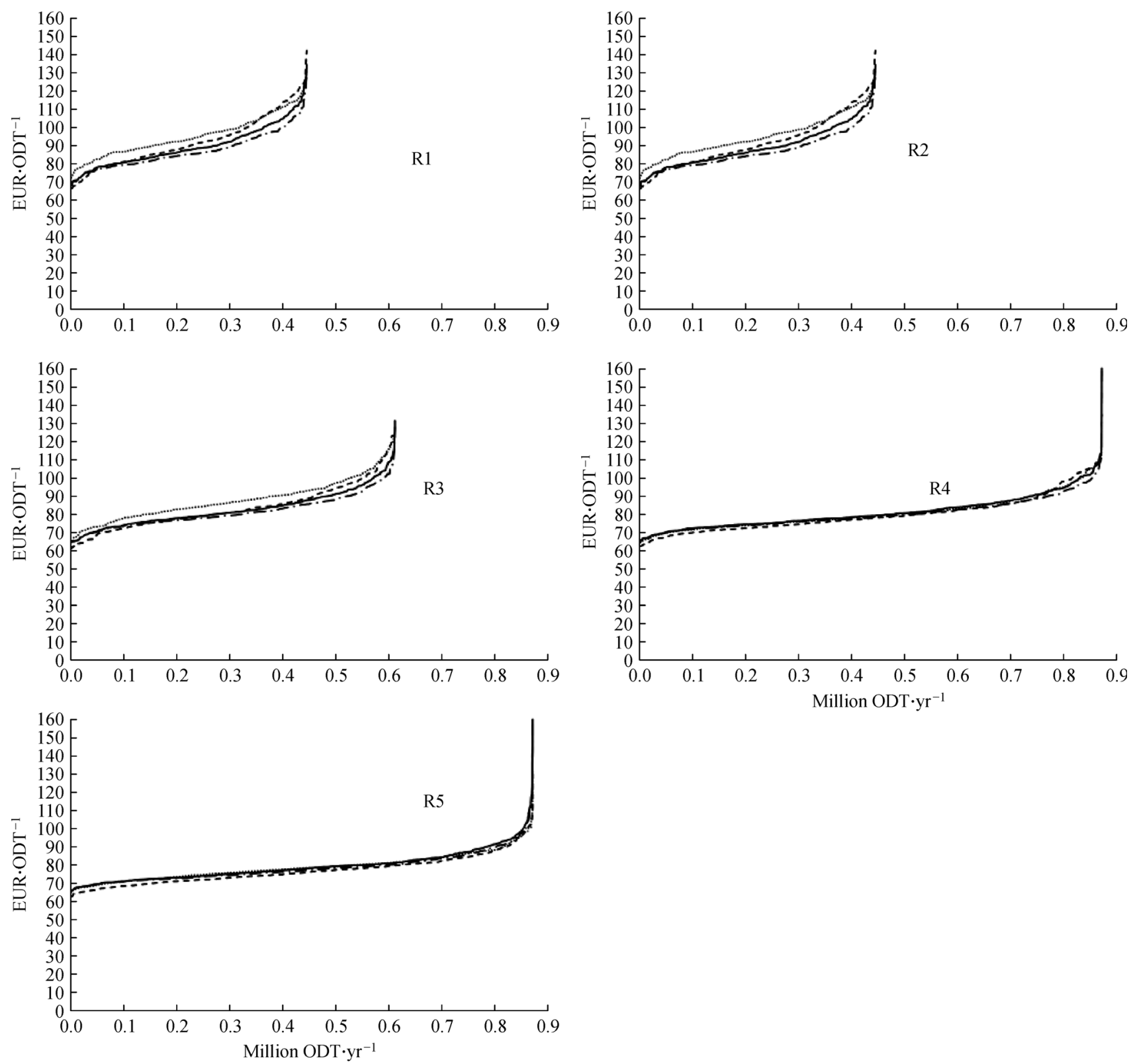

Fig. 2 Marginal costs for procurement of logging residues in R1-R5. Logging residues-Systems 1 (solid line), 2 (round dot line), 3 (dash line) and 4 (long dash dot line). See Table 1 for system description.

\section{Discussion}

The present study shows that there is a potential to increase the supply of forest fuel to heating and CHP facilities. The forests of northern Sweden are a great asset that is not yet fully utilized mainly due to lack of profitability for those involved. The extraction of the whole technical potential (Level 3 in this study) depends on the willingness of the forest owners to take out forest residues, stumps and young trees from early thinnings as well as on the use of supply chains that are designed and managed in such a way that they are profitable. Indeed, Windisch et al. ${ }^{[14]}$ showed that the application of a supply chain management in two forest owners associations was able to improve the efficiency and profitability of the forest fuel supply chains.

Previous studies have estimated forest fuel availability in Sweden within the range 47 to $129 \mathrm{TWh}^{[15]}$. In this study, the technical potential reached about $43.7 \mathrm{TWh}$ (9.39 million ODT). According to the official statistics of Sweden ${ }^{[16]}$ about $12 \mathrm{TWh}$ of forest fuels is extracted annually from the forest. As this is mostly logging residues it means that $74 \%$ of the available logging residues is already utilized and that an increased use of stumpwood and small diameter trees is needed.

The present study provides insight for future studies that will concentrate on areas R1, R2 and R3 (Fig. 1). These 

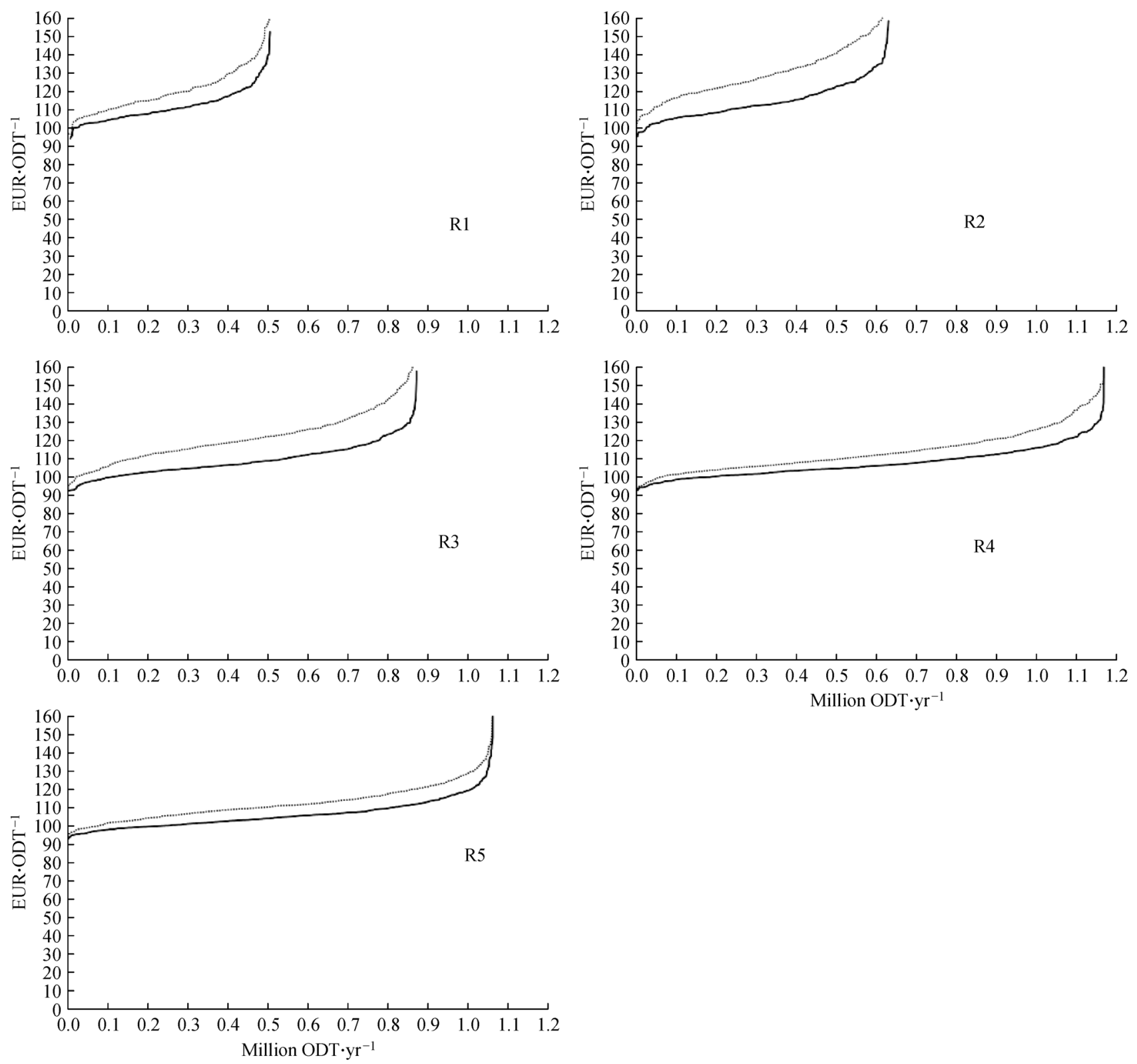

Fig. 3 Marginal cost curves for stumps in R1-R5. Stumps-Systems 1 (solid line) and 2 (round dot line).

regions hold $45 \%$ of the potential and only $45 \%$ of the area that will be regeneration felled was considered for logging residue extraction in 2011 according to unpublished data from the Swedish Forest Agency. In contrast, the area considered for logging residue extraction reaches $80 \%$ in the south of Sweden.

The approach outlined in this paper offers a regional perspective of the costs of supplying facilities with logging residues and stumps. Each region has a network of terminals, facilities and forest inventory plots. Only facilities that had reported to use more than $100 \mathrm{GWh}$ of biofuels (logging residues, bark, sawmill by-products, wood waste, pellets, briquettes and peat) in 2009 were included in the study. If more facilities and terminals had been counted within each region the slope of the marginal cost curves would have been more moderate, i.e., it would have been less costly to transport the forest fuel to the facilities/terminals.

In the present study, each region was treated independently of the others, i.e., a facility/terminal that was located in a certain region could only obtain logging residues and stumps from its own region. Co-operation between facilities owned by the same company and competition among different facilities within the same region were not considered.

Information on the economic availability of logging 
Table 6 Regional demand of biofuel by heat and combined heat and power plants, available potential (Level 3) of logging residues, stumps and small diameter trees and regional balances/GWh

\begin{tabular}{lcccc}
\hline Region & $\begin{array}{c}\text { Facilities with bioenergy demand } \\
\text { of }>100 \mathrm{GWh}\end{array}$ & $\begin{array}{c}\text { All facilities independently on } \\
\text { bioenergy demand }\end{array}$ & Available potential & Balance \\
\hline R1 & 1358 & 1800 & 4511 & 2711 \\
R2 & 517 & 930 & 5859 & 4929 \\
R3 & 1578 & 2300 & 8928 & 6628 \\
R4 & 15946 & 18204 & 12695 & -5509 \\
R5 & 8399 & 11066 & 11672 & 606 \\
Sum & 27798 & 34300 & 43665 & 9365 \\
\hline
\end{tabular}

residues and stumps in each region is important for biofuel suppliers and receiving facilities. The regional potential assessment and the marginal cost curves together show that logging residues and stumpwood in R1, R2 and R3 are sufficient, and in R5 close to enough, to provide all bioenergy demand if this was met only by logging residues and stumps. R4 has a deficit that would be difficult to cover without imports from other countries or regions. The analysis also shows that new facilities and biorefineries could be established in the northern regions.

As with other studies ${ }^{[17-19]}$, forest inventory plots were used in this study. Optimization was not used, as the aims were only to give an estimation of the regional potential and the cost of transport to the closest facility or terminal. However, in a previous study, an optimization model was used to estimate the amount of logging residues and stumps in north Sweden that could be transported to different facilities taking into consideration the proximity of the facility, the amount of logging residues and stumps in the forest and two scenarios of facility demand ${ }^{[20]}$.

\section{Conclusions}

- The harvestable potential of forest fuels (logging residues and stumps from regeneration fellings and small trees from early thinning) in Sweden amounts to 9.4 million ODT $\cdot \mathrm{yr}^{-1}$.

- Procurement costs for logging residues start from $60 \mathrm{EUR} \cdot \mathrm{ODT}^{-1}$ while for stumps from $90 \mathrm{EUR} \cdot \mathrm{ODT}^{-1}$.

- In the case that the total potential of logging residues, stumps and small diameter trees was actually utilized by heat and combined heat and power plants in Sweden all feedstock need for combustion would have been satisfied.

Acknowledgements This study was financed by the research program Effektivare skogsbränslesystem (More effective systems for forest fuel harvesting), the Botnia Atlantica projects Forest Refine and BioHub, and Bio4Energy.

Compliance with ethics guidelines Dimitris Athanassiadis and Tomas Nordfjell declare that they have no conflicts of interest or financial conflicts to disclose.
This article does not contain any studies with human or animal subjects performed by any of the authors.

\section{References}

1. European Commission. Citizens' summary-EU climate and energy package

2. Swedish Energy Agency. Energy in Sweden, 2015

3. Swedish District Heating Association. District heating 2030

4. Athanassiadis D, Melin Y, Nordfjell T, Lundström A. Harvesting potential and procurement costs of logging residues in Sweden. In: Proceedings of the 4th International Bioenergy conference, Bioenergy 2009-Sustainable Bioenergy Business. Jyväskylä: FINBIO publication 44, 2009, 293-300

5. Lundström A, Söderberg U. Outline of the Hugin system for longterm forecasts of timber yields and possible cut. In: European Forest Institute, Proceedings No.5. Large-scale Forestry Scenario Models; Experiences and Requirements. Joensuu: European Forest Institute, 1996

6. Swedish Forest Agency. Forest consequence analysis, 2008

7. Nurmi J. Recovery of logging residues for energy from spruce (Picea abies) dominated stands. Biomass and Bioenergy, 2007, 31 (6): 375-380

8. Berg S. Terrain Classification System for forestry work. Uppsala: Forestry Research Institute of Sweden, 1992

9. Athanassiadis D, Nordfjell T, Lundström A. A Regional-Scale GISBased Evaluation of the potential and Supply Costs of stumps in Sweden. In: Proceedings of Tree stumps for Bioenergy. 2011, Uppsala: Swedish University of Agricultural Sciences, 2011

10. Nordfjell T, Nilsson P, Henningsson M, Wästerlund I. Unutilized biomass resources in Swedish young dense stands. In: Proceedings of World Bioenergy 2008. Jönköping: Swedish Bioenergy Association, 2008: 323-325

11. Athanassiadis D, Melin Y, Lundström A, Nordfjell T. Marginal costs for harvesting of logging residues and stumps in final fellings in Sweden. Arbetsrapport 261. Umeå: Department of Forest Resource management; Uppsala: Swedish University of Agricultural Sciences, 2009 (in Swedish)

12. v Hofsten H, Lundström H, Nordén B, Thor M. Systems analysis of energy-wood harvesting - a tool for continued development. Resultat nr 6. Uppsala: Forestry Research Institute of Sweden, 
2006 (in Swedish)

13. Ringman M. Wood fuel assortments- definitions and properties. Report no. 250. Uppsala: Swedish University of Agriculture Sciences, 1996 (in Swedish)

14. Windisch J, Sikanen L, Röser D, Gritten D. Supply chain management applications for forest fuel procurement-cost or benefit? Silva Fennica, 2010, 44(5): 845-858

15. Lundmark R. Cost structure of and competition for forest-based biomass. Scandinavian Journal of Forest Research, 2006, 21(3): 272-280

16. Swedish Forest Agency. Swedish Statistical Yearbook of Forestry, 1942-2014.

17. Panichelli L, Gnansounou E. GIS-based approach for defining bioenergy facilities location: a case study in Northern Spain based on marginal delivery costs and resources competition between facilities. Biomass and Bioenergy, 2008, 32(4): 289-300

18. Rørstad P K, Trømborg E, Bergseng E, Solberg B. Combining GIS and forest modelling in estimating regional supply of harvest residues in Norway. Silva Fennica, 2010, 44(3): 435-451

19. Stasko T H, Conrado R J, Wankerl A, Labatut R, Tasseff R, Mannion J T, Gao H O, Sanborn S D, Knott G. Mapping woodybiomass supply costs using forest inventory and competing industry data. Biomass and Bioenergy, 2011, 35(1): 263-271

20. Athanassiadis D, Lundström A, Wikström P, Matisons M, Nordfjell T. Is there enough primary forest fuel available to feed into the existing and planned CHP facilities? The case of Northern Sweden. In: Proceedings of Forest Bioenergy 2010, Tampere. Finland: FINBIO publication 47, 2010, 77-83 